COGNITIVE STUdies | ÉTUdes COGNITIVES, 15: 397-411

DOI : $10.11649 / \mathrm{cs} .2015 .028$

\author{
WOJCIECH SOSNOWSKI ${ }^{1, A}$ \& PASCAL BONNARD ${ }^{2, B}$ \\ ${ }^{1}$ Institute of Slavic Studies, Polish Academy of Sciences, Warsaw, Poland \\ ${ }^{2}$ Humboldt-Universität, Berlin, Germany

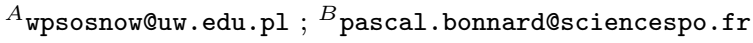

\title{
THE CURRENT EVOLUTION OF SLAVIC LANGUAGES IN CENTRAL AND EASTERN EUROPE IN THE CONTEXT OF THE EU MULTILINGUALISM POLICY
}

\begin{abstract}
The respect for and protection of cultural and linguistic diversity have long been guaranteed in various international and European legislative acts. More recently, the European Union has also developed laws aimed at the preservation and promotion of multilingualism. Linguistic diversity has long been seen as an obstacle to the effective functioning of EU institutions. Recently, however, it has been considered as a valuable "heritage" of the EU. In our article, we will present a brief overview of policies promoting multilingualism in Europe, and more specifically, in the EU. Subsequently, we will compare this framework to the changes occurring presently in modern Slavic languages of Central and Eastern Europe. The tendency of these languages towards increased analitism transforms these predominantly synthetic languages into more analytical ones. These conclusions have led us to the following question: What is the current state of modern Slavic languages and how far may their evolution be addressed by policies promoting multilingualism? Our analysis consists of two parts: first, we scrutinised various European legislative acts promoting multilingualism; second, we analysed modern Slavic languages by means of the parallel corpora of chosen languages from the Common Language Resources and Technology Infrastructure project (including UNESCO and EU legislation, etc.).

Keywords: multilingualism; EU policies; analytical tendencies; analitism; trilingual parallel corpora; theoretical contrastive linguistics; contrastive non-lexical and lexical semantics
\end{abstract}

The respect for and protection of cultural and linguistic diversity have long been guaranteed in various international and European legislative acts. More recently, the European Union also adopted legislative acts and developed policies aimed at the preservation and promotion of multilingualism. This went as far as to create 
in 2006 a specific portfolio for multilingualism in the Commission, which went, from 1 January 2007, to the Romanian politician Leonard Orban. Though the experience did not last very long - in the second Barroso Commission, this policy field went back to the education and culture portfolio (where it had been introduced as a specific subject as of 2004) - it highlights the strong recognition the label "multilingualism" gained over the years and testifies that the European Union has developed a substantial policy in this area.

We will investigate three issues related to the EU multilingualism policy: (1) how the multilingualism policy was developed; (2) how languages evolve as a result of interaction with other language systems; (3) what modern technologies can be used to study European languages and their mutual impact on one another. We will in conclusion be able to address the question whether the designed instruments are suitable to tackle the specific situation of languages in Central and Eastern Europe.

The development of a multilingualism policy is striking, if one keeps in mind that the EU has no real legal competence to run a language policy stricto sensu (usually understood as the set of measures aimed at regulating language practices in a given society). As language is closely related to the building of national identity, national states tend to be highly sensitive towards any intervention from outside in this field. Governments of EU member states are therefore in charge of deciding which languages are to be used for official communication and of codifying and implementing the uses of the official language(s). Arguably, from the very beginning of the creation of the European communities, some decisions had to be taken in the field of language politics to ensure the good functioning of the institutions. Since then, however, European institutions substantially extended the area of their intervention. Over the following pages, the emergence and progressive institutionalization of the EU "multilingualism policy" will be examined. This overall query includes a second order question, which addresses the role of the eastward enlargement in the development and design of the multiculturalism policy.

The EU multilingualism policy: A multi-layered policy

The European communities progressively developed a range of actions in the field of language politics, driven by different motivations.

The languages of the European institutions: The "language regime" and its practice The 1957 establishment of the European Economic Community and European Atomic Energy Community was intended to create economic integration between the former belligerents of the Second World War, through which the reiteration of such dramatic events shall be prevented. Territorial claims, hostile speeches and policies were to be given up and interstate relations to be built on mutual recognition. Hence, equality of the stakeholders (the member states) was made to, and remains, an ontological principle of the establishment and functioning of the Communities. When the heads of states or governments gathered in 1958 to determine which languages were to be used for the purpose of official communication by and within the institutions of the Communities, they consequently decided that the official language(s) of each member state were the official and working languages of these institutions ("EEC Council 1958: Regulation No 1 determining the languages to be used by the European Economic Community", Official Journal, 
017, 06.10.1958, pp. 385-386; "Règlement $\mathrm{n}^{\circ} 1$, portant fixation du régime linguistique de la Communauté européenne de l'énergie atomique", Official Journal, 017, 06.10.1958, pp. 401-402). ${ }^{1}$

Parallel to this principle of strict equality, an officious practice, however, progressively appeared to resort to an intermediate language. In the mid-1990s, French began to be used as a pivot language for interpretation into Greek and Portuguese in the European Parliament. Nowadays, six pivot languages are used (English, French, German, Italian, Polish and Spanish). This appeared to be necessary to alleviate the increase of costs related to the growing number of EU official languages. For obvious reasons, some languages also tend to be more used than others in everyday communication within the institutions. French, following a long of period of dominance, has been mostly displaced by English. For example, $72 \%$ of the EU texts are nowadays produced in English.

Besides, some EU institutions make use of the right given to them to "stipulate in their rules of procedure which of the languages are to be used in specific cases" (art. 6 of the 1958 Regulation) and restrain the number of their working languages: French is the working language of the European Court of Justice, as English is that of the European Central Bank. ${ }^{2}$ These practices, however, remain officious or are regarded as exceptional, and the commitment to the principle of language equality remains very vivid. Alleged excessive use of a language is indeed regularly denounced by national representatives: since the beginning of the 1990s, numerous questions have notably been asked by Members of the European Parliament regarding the extension of the use of English.

Though the principle of language equality sometimes falls under criticism because of the significant costs it generates, it has therefore been constantly reaffirmed. In 1982 for example, the European Parliament confirmed "the rule that there is to be absolute equality between the Community languages, whether used actively or passively, in writing or orally, at all meetings of Parliament and its bodies" ("Resolution on the multilingualism of the European Community", Official Journal, C 292, 08.11.1982, pp. 96-97).

Fostering foreign languages learning: A various and extending array of initiatives Foreign languages learning is maybe the most straightforward dimension of the multilingualism policy. The interest shown by European leaders and civil servants for this dimension traces back to the end of the 1970s. The European Community, however, had originally no competence in educational matters. This is the

\footnotetext{
${ }^{1}$ The language regime is modified only at the occasion of an enlargement. The case of Irish, that became an official language of the EU only in 2007 (following the "Council Regulation No 920/2005 of 13 June 2005 amending Regulation No 1 of 15 April 1958 determining the language to be used by the European Economic Community and Regulation No 1 of 15 April 1958 determining the language to be used by the European Atomic Energy Community and introducing temporary derogation measures from those Regulations", Official Journal, L 156, 18.06.2005, pp. 3-4), testifies that the state is responsible for its language(s) to be registered as official by the EU. Read Milian i Massana (2002) for a comprehensive (juridical) presentation of the evolution of the EU language regime.

${ }^{2}$ For a more differentiated overview of the EU language regime by EU institution, read Pozzo \& Jacometti (2006). For a detailed analysis of the effective language practices by and within EU institutions, read Haselhuber (2012, pp. 33-128).
} 
"increasing awareness of the economic aspects of education [that] has led to regular Community cooperation in this field" (Coulmas, 1991, p. 9). First major activities could be launched by the end of the 1980s with the Erasmus and Lingua programmes, respectively in 1987 and $1989 .{ }^{3}$ In 1995, the Socrates Programme was established to gather the different Communities' initiatives in the educational field (notably Lingua and Erasmus) and language learning constituted one of its core goals. Within the same year, the European Council specified that every EU resident shall command at least two foreign languages.

The commitment of the EU towards reinforcing language competences has been pursued ever since. Both the Lingua and Erasmus programmes have been renewed and they were supplemented by further initiatives. In 2004 the Erasmus Mundus program was established with the aim to foster the knowledge of languages from countries that are located outside of the EU. More recently, migrant languages started to be considered as languages, whose learning was to be encouraged (Rindler Schjerve \& Vetter, 2012, pp. 34-35). Acquiring and reinforcing one's language competences also became part of the "action program in the field of lifelong learning", which may therefore be pursued all life long (Official Journal, L 327, 24.11.2006, pp. 45-68).

Regional languages and culture: Protecting and promoting the European "common cultural heritage"

At the end of the 1970s, EC institutions also started to face demands on minority rights. The situation of minorities and their claims were addressed in several reports and debates within the European Parliament. Following the Arfé report, the European Parliament adopted in 1981 a resolution on the Community Charter of regional languages and cultures and on a charter of rights of ethnic minorities (Official Journal, C 287, 09.11.1981, p. 106). Regional languages were cast as being an integral part of the European "common cultural heritage" or "civilization" (according to the expression used in the 1981 resolution) and, therefore, as deserving the support from the European Communities (Scheidhauer, 2001). The EU later regularly repeated its commitment to the protection of regional languages; this is covered by Article 22 of the Charter of Fundamental Rights of the European Union, according to which "the Union shall respect cultural, religious and linguistic diversity" (Official Journal, C 364, 07.12.2000, p. 13).

The "heritage" argument also guided the establishment of a common cultural policy. In the conclusions of a meeting aimed at drawing guidelines for Community cultural action in November 1992, EU Ministers of Culture assigned to this policy the goals of "[respecting] national and regional diversity [linguistic diversity is included within] and, at the same time, [bringing] the common cultural heritage to the fore" (Official Journal, C 336, 19.12.1992, pp. 1-2). These goals were pursued by the Media (since 1991) and, later, Culture (since 2000) programs, before being merged into the most recent Creative Europe program (2014-2020).

\footnotetext{
${ }^{3}$ For an extensive presentation of the action of the EU aimed at promoting the learning of foreign languages, read Kruse (2012).
} 
"Multilingualism" as an "umbrella term"

The term "multilingualism" began to be increasingly used from the mid-1990s (Rindler Schjerve, 2011, p. 151 and following). Different dimensions of EU language initiatives were progressively brought together under the umbrella of this notion. Two legal acts stood out above the process of consolidation of the EU multilingualism policy. The decision issued in 2000 by the European Parliament and the Council on the establishment of the European Year of Languages 2001 is the first occasion where "multilingualism" occurs in a text that encompasses such a broad spectrum of activities. They range from the language institutional regime to language teaching, and the protection of cultural diversity or the support for more tolerant attitudes (Official Journal, L 232, 14.9.2000, pp. 1-5). The adoption by the Council in 2008 of the New Strategy for multilingualism (Official Journal, C $320,16.12 .2008$, pp. 1-3) follows the creation of a portfolio for multilingualism and the presentation of the end report prepared by the high-ranking group on multilingualism established in 2006. This text synthetizes the different language actions identified above in a multilayered policy and gives guidelines to EU institutions. The adoption of this "multilingualism policy" therefore highlights that the EU has an extensive set of goals and instruments in the field of language policies.

\section{The EU multilingualism policy and eastward enlargement}

The 2004 and 2007 enlargements significantly increased the number of member states, the size and population of the EU and also put new topics, such as those of minorities, on the EU agenda. Therefore, the eastward expansion of the EU has been a great challenge to its action in the field of language politics.

An institutional regime challenged but reinforced

The 2004 and 2007 enlargements dramatically increased the number of official languages of the EU: this number doubled from 11 to $22 .{ }^{4}$ This unprecedented increase was a source of strong concern among EU and national officials. In the years preceding the enlargement, the sustainability of the institutional language regime that relies on a strict equality of all EU languages was questioned by Members of the European Parliament and reports were drafted to discuss possible alternatives to multilingualism (Ricci, 2006, pp. 135-139). Looking back at the previous enlargements indicates that these debates are actually recurrent. At the beginning of the 1990s, analysts were already skeptical about the capacity of the European Communities to maintain their language regime in the case of further enlargements (Labrie, 1993). In fact, the proportion of the EU budget dedicated to translation and interpretation remained stable over time. In 2014, the European Commission claims that the costs of translation and interpretation amount to less than $1 \%$ of the annual EU budget (Häggman, 2014). 30 years earlier, in 1982, the estimation given by the European Parliament was slightly higher, namely of "about $2 \%$ of the Community's total budget" ("Resolution on the multilingualism of the European Community", Official Journal, C 292, 08.11.1982, p. 97). This adhesion wave did not therefore significantly change the situation.

\footnotetext{
${ }^{4}$ As mentioned above, Irish was also added during the same period. With Croatia joining the EU in 2013, 24 languages are therefore official languages of the EU.
} 
Notwithstanding initially voiced concerns due to the enlargements, the importance of maintaining the EU language regime has been reaffirmed. According to the European Parliament, "linguistic diversity will not in reality be further eroded. Any discrimination against any of the official languages must be excluded. This principle must continue to apply after any enlargement of the European Union." ("European Parliament decision on the adoption of a Statute for Members of the European Parliament", Official Journal, E 068, 18.03.2004, p. 118) At the same time, the higher number of official languages made even more necessary the practice of resorting to pivot languages. The asymmetric use of EU official languages increased, as has the predominance of English within and outside the institutions. Rather than undermining its language regime, the eastern enlargement therefore reinforced it.

Minorities in Central and Eastern Europe: Limits and opportunities for the EU multilingualism policy

The reproach has long been made to the EU that its mechanisms to protect minority languages are insufficiently developed, if not missing (Woehrling, 1992). Although, as stressed above, they were petitioned since the end of the 1970s by militants championing the minority rights, the European communities did not get directly involved in this field. The eastward expansion of the EU, however, offered a unique occasion to upgrade this policy. The outburst of ethnic violence in former $\mathrm{Yu}$ goslavia and, more generally, the idea prevailing in the West that Central and Eastern countries are characterized by a high degree of ethnic diversity that could be a source of instability for the whole continent prompted European organisations to strengthen their system of minority protection (Cordell, 2013). The European Community firstly limited itself to resorting to the expertise of the Council of Europe: the ratification of the COE's Framework Convention for the Protection of National Minorities was made compulsory for candidate countries in 1993 and the ratification of the European Charter for Regional or Minority Languages was encouraged. The EU later included these norms in its own legislation: in 2000, the principle of protection of minorities has been included in the Charter of Fundamental Rights, which acquired binding legal status in 2009 (art. 6 of the Lisbon Treaty). The increased concern of the EU over minority issues did not, however, lead to a more systematic action of the EU regarding minority languages and it remains relatively poorly institutionalized within the multilingualism policy (Nic Craith, 2006).

The EU has progressively developed a comprehensive set of policies (more or less institutionalized) aimed at enhancing and protecting multilingualism. The eastward enlargement played a non-negligible role in giving this policy its current shape. Far from undermining the language regime, it actually contributed to reinforce it. Besides, the enlargement to Central and Eastern European countries prompted the EU to pay more attention to minority issues and, hence, to refine its action in this regard and institutionalize minority norms.

It remains to be assessed, however, whether these tools are suitable to face the challenges of the current linguistic situation in the Central and Eastern Europe. Over the following pages, we will highlight two specific but crucial characteristics 
of the evolution of the linguistic landscape in the region: firstly, the evolution of Slavic languages from synthetic towards analytic and, secondly, the incorporation of EU jargon into these languages. These trends are based on the examination of one official language of the EU (Polish) and one language that is not granted any status in the EU countries but is nonetheless present (Russian).

Let us emphasise that whenever people use a language in different channels of communication and in translation (mainly translations from dominant languages, which are analytic in their structure, i.e. English and French), it results in an ongoing change to that language's structure. These processes are natural and they cannot be stopped.

Theoretical contrastive studies. Theoretical contrastive studies derive from contemporary semantic theory and contrastive studies of natural languages developed in the multi-volume Gramatyka konfrontatywna butgarsko-polska (19882007) [further referred to as: GKBP] (Koseska-Toszewa \& Gargov, 1990; KoseskaToszewa, 2006; Koseska-Toszewa, Korytkowska, \& Roszko, 2007). GKBP is the first contrastive grammar in the world to make use of an intermediate semantic interlanguage. Using a semantic interlanguage to compare multiple languages provides an innovative solution for contrastive studies and diverges from traditional principles of applied contrastive studies. Traditionally, the comparison between two (or more) languages relies heavily on the primary language of description, therefore it is always incomplete and can also be misleading, if not grossly innacurate.

From meaning to form. In theoretical contrastive studies, the analysis of language data proceeds from meaning to form. This stands in contrast to traditional contrastive grammars, which tend to start with a form in one language and then proceed to a form in another language. This type of analysis was used during the creation of the Russian-Bulgarian-Polish Dictionary (Koseska-Toszewa, SatołaStaśkowiak, \& Sosnowski, 2013a, 2013b; Kisiel, Satoła-Staśkowiak, \& Sosnowski, 2014), where we began with a form only in the primary language of the dictionary; subsequently we define the meaning of this form using Polish. Thus, the definition of the meaning of a form in the primary language is the starting point for the search of its equivalents in the second and third languages (or more if needed). The above procedure - outlined in GKBP - enables us to treat the data from every language as equal. Our procedure is quite similar to the latest methodology of Stowosieć 2.2 (http://plwordnet.pwr.wroc.pl/wordnet/) - the comprehensive electronic dictionary of Polish and the largest word-net in the world.

Clarin and parallel corpora. The data we collected come from the national and multilingual corpora that are part of CLARIN: the National Corpus of Polish, the Bulgarian-Polish Parallel Corpus (ed. L. Dimitrova \& V. Koseska-Toszewa), the Polish-Bulgarian-Russian Parallel Corpus (ed. V. Koseska-Toszewa, W. Sosnowski, J. Satoła-Staśkowiak, \& A. Kisiel), and the Russian National Corpus (http://www.ruscorpora.ru). We also have on-going access to the 6-milion-word Polish-Bulgarian-Russian corpus developed by the Department of Corpus Linguistics and Semantics of the Polish Academy of Sciences. Last but not least, some data also come from multiple spoken and written sources, authors' own data collected 
Table 1:

\begin{tabular}{|l|r|r|r|}
\hline \multicolumn{1}{|c|}{ Name of the document } & PL & BG & RU \\
\hline Statute of the Council of Europe & 2925 & 4712 & 3171 \\
\hline European Charter of Local Self-Government & 2037 & 2317 & 1958 \\
\hline European Social Charter & 10058 & 11000 & 8756 \\
\hline European Cultural Convention & 1029 & 1107 & 932 \\
\hline European Convention on Extradition & 3300 & 3436 & 3312 \\
\hline $\begin{array}{l}\text { Convention for the Protection of the Architectural Heritage } \\
\text { of Europe }\end{array}$ & 2281 & 2687 & 2259 \\
\hline $\begin{array}{l}\text { European Convention on Mutual Assistance in Criminal } \\
\text { Matters }\end{array}$ & 1165 & 1338 & 1133 \\
\hline European Convention on Transfrontier Television & 4765 & 5449 & 5951 \\
\hline $\begin{array}{l}\text { European Convention on Recognition and Enforcement of } \\
\text { Decisions concerning Custody of Children and on Restora- } \\
\text { tion of Custody of Children }\end{array}$ & 3340 & 3804 & 3327 \\
\hline $\begin{array}{l}\text { European Convention for the Prevention of Torture and In- } \\
\text { human or Degrading Treatment or Punishment }\end{array}$ & 2191 & 2426 & 2178 \\
\hline Convention on Cybercrime & 8734 & 9960 & 8899 \\
\hline $\begin{array}{l}\text { Convention for the Protection of Individuals with regard to } \\
\text { Automatic Processing of Personal Data }\end{array}$ & 2941 & 3173 & 2879 \\
\hline Convention on the Transfer of Sentenced Persons & 2743 & 3250 & 3032 \\
\hline The Universal Declaration of Human Rights & 1710 & 1800 & 1634 \\
\hline Kyoto Protocol & 7045 & 7814 & 7016 \\
\hline
\end{tabular}

throughout their careers, as well as some research papers in linguistics (cf. References, p. 408). The Table 1 shows examples of documents that served as sources for the Polish-Bulgarian-Russian Corpus (the count of words in each language is given in a separate column).

Analitism and analytic tendencies. Modern Polish, Russian and other synthetic Slavic Languages are characterized by some features that demonstrate an increasing level of analitism. In the process of transformation from synthetic to analytical language, a crucial role is played by prepositional units.

To illustrate this tendency, modern Bulgarian and its history have been applied as an example of analytical language. In this research, analitism is understood in a traditional way i.e. as a morphological and syntactic phenomenon. It means that grammatical categories which were previously expressed through inflectional forms are beginning to be signalled by separate formal indicators in the form of separate words. In the process of the language becoming more analytical, the role of "helper" 
words has increased, which has led to the disappearing declination of nominative forms, whose function has been superseded by prepositions and word order. The replacement of one case by another, or the process of eliminating one of the forms in favour of others which are dominant in the declination paradigm, may be viewed as a phase in rearranging the synthetic system into a more analytical one. The condition of each modern literary language is a result of consistent changes that have occurred in it. For this article, the condition of Polish and Russian in the second decade of the 21st century has been analysed. The claim that a gradual expansion of the corpus of prepositional units in Polish and Russian led to analitism was met with opposition and outrage from scientists, linguists and language teachers even in the 1990s. Our compilation of the corpus of Russian pronouns in 2000 has given rise to further research into the problem of analitism in Slavic languages. At the turn of the 21st century, a large number of scientists began collecting bodies of Slavic prepositions due to the fact that this part of speech had been analysed in least detail for particular Slavic languages. The fact that the synthetic structure of a language may in some conditions turn into an analytical one, which has occured in the case of Bulgarian and Macedonian languages, has been intriguing linguists ever since, and has prompted us to answer the question: what is the condition of modern Polish and Russian and should they be considered synthetic or analytical languages?". Thanks to observing processes occurring in both languages over the last 10 years, comparative analysis and collection of materials, the level of their analysis has been characterized, and, through comparing some examples, the corpora of prepositional units and other units turning into prepositions has been gathered.

Having analysed the history of Slavic analitism, and having presented the most important findings in the development of Slavic languages from Indo-European languages to modern times, we have discovered some regularities. The works and research of Z. Stieber (1979), D. Stanisheva $(1968,1980,1982)$ and J. Rusek (1964) have helped us to present the road of the Bulgarian language to analitism and the growing role of prepositions. Together with the form of the common case, the preposition has become the only factor of syntactic relationship which, so far, has been expressed solely through case endings.

We have based our analysis on the research of E. Zemskaia, who, in her work, confirms the increasing role of agglutination in Russian, and on the work of Z. Rudnik-Karwatowa dealing with the increase of uninflected prefixes. Uličný studied the recent analytic trends in Czech (Uličný, 2013) on the basis of up-to-date language data.

The analytical tendencies in morphology include the following: a decrease in the number of cases in all inflected parts of speech (Pl: funduszy instead funduszów, $\mathrm{Ru}$ : не принимать меры instead не принимать мер; a more frequent use of uninflected nouns and adjectives (Pl: biopaliwo, е-росzta, $\mathrm{Ru}$ : еврозона); the growing importance of nouns with common gender, and, in particular, the use of forms of masculine gender to depict feminine gender (Pl: polska komisarz Danuta Hübner); differences in expressing collectiveness in a group of nouns (using collective meaning for forms that have singular meaning (Ru: гражданин Европы ждёт новых методов)); substituting case forms with prepositions; substituting case forms with subordinate clauses (Pl: anologicznie do, anologicznie $z$, $\mathrm{Ru}$ : в дополнение $\kappa$ про- 
токолу, в дополнение протокола, конвенция по, конвенция о); substituting case forms with "helper" words (Pl: jak, jako, Ru: кaк).

Analytical tendencies in the area of numeral functioning include: substituting inflected forms of ordinal numerals with cardinal ones (Pl: w paragrafie 17 (siedemnаście), Ru: в статье 21 (двадиать один)) the gradual disappearing inflection of numerals; confusing the forms of noun cases after numerals; the disappearing declination of collective numerals (Pl: piatka dzieci, Ru: пять суток instead nятеро суток); displacing other cases with so-called simple cases (Pl: dwoma ustawami instead dwiema ustawami); changing the syntactical position which the numeral should be inflected in; abandoning the declination of first elements of collective numerals (Pl: strona pięćdziesiąt instead strona piećcdziesiąta).

During the study of analytic tendencies in morphology, it was necessary to examine personal pronouns as this part of speech seems to be the most stable as far as other forms except nominative are concerned. Having analysed the material, it can be claimed that analitism in Slavic pronouns is observed at the level of the replacement of short forms with full ones, through the use of various forms after prepositions and eliminating all the alternative forms of personal pronouns.

This review of analytic tendencies has also involved studying the article and its role in analytic languages, as the article is the area of a language which should be filled while the inflection disappears. Having analysed the material, we have concluded that there is a possibility that the article may appear in Polish and Russian.

The most important part of speech in analytic languages is the preposition. An increase in the number of prepositional units is said to be an essential element of syntactic transformation in 20th century Polish and Russian. In accordance with this tendency, secondary prepositions are gradually replacing proper prepositions and case forms in their traditional usage. The secondary preposition has been defined as a lexical unit, not being a preposition initially but used secondarily in this function. Such a definition requires adopting a functional perspective in the description, more so because the transformation of various language units (nouns, prepositional phrases, adverbs, conjunction, phraseological nexuses) into prepositions takes place gradually and the same set can be interpreted otherwise in different contexts. This comprehensive analysis of two modern Slavonic languages shows that the number of prepositional units in both languages has grown and is still increasing (Pl: w świetle; w odpowiedzi na; z uwagi na; odnośnie do; co do; w иzиреtnieniu; Ru: в согласии с; совместно с; под патронатом; в аспекте).

Lexical changes. Documents produced in EU institutions are often needlessly overcomplicated due to high use of specific jargon, which is later also carried over in the translations (Miodek et al., 2010, p. 7). Moreover, many foreign words and expressions are carelessly copied into Polish, Bulgarian and Russian often in order to make a text appear more legitimate or sophisticated. This phenomenon does not only stem from Poland's presence in the EU - it is mainly a result of people being influenced by language 'fads' (cf. e.g. Miodunka, 1999).

Languages constantly evolve and change. Consequently, neosemanticisation is inherent in this process and will always take place. The change that a language 
undergoes does not only involve internal transformations of its system - it also changes under the influence of other natural languages. (cf. Satoła-Staśkowiak, 2014, p. 187), Pl: agresywny, Bg: агресивен; $\mathrm{Pl}$ : proтосjа, Bg: промочия; Pl: nominacja, Bg: номиначия; Pl: indeksacja, Bg: индексачия; Pl: klubowy, Bg: клубен; Pl: kopiować, Bg: копирам; Pl: artykułować, Bg: артикулирам (qtd. after Satoła-Staśkowiak, 2014, p. 187).

The most recent lexemes that appeared in Polish are: akredytacja, alokacja, aplikowanie, ewaluator, termin indykatywny, monitoring projektów, okres programowania, runda aplikacyjna [accreditation, allocation, evaluator, indicative date, project monitoring, programming period, application round] and many others. The above words and expressions had not existed in Polish before Poland's accession to the EU or — if they had existed - their presence was limited to highly specialised texts. If a text was aimed at a wider audience, their authors would rather use their more established equivalents: uprawnienie, rozdysponowanie, ubieganie się o coś, osoba kontrolująca (badająca), orientacyjny termin, nadzorowanie projektów, lata obowiazywania programów and czas na składanie wniosków respectively.

We can also observe a dangerous trend among public servants — high-level officials often prefer foreign words and constructions to their normal Polish equivalents. This process derives from their conviction that official documents should sound grand and sophisticated. Moreover, people and institutions applying for EU grants often suffer a less favourable treatment, if they fail to use the 'proper' (i.e. foreign-sounding) vocabulary.

Apart from borrowing foreign words to replace existing Polish lexemes, language users also add new meanings to words that were previously used in very limited contexts (cf. Markowski, 2004). These processes had existed in Polish even before Poland's accession to the EU (Maćkiewicz, 2001), however, the accession spurred a rapid development of such trends. The word kondycja 'condition, stamina, endurance' used to refer exclusively to one's stamina; recently, it has acquired its English-like meaning of general condition or state of any referent, also non-human (e.g. kondycja polskiej gospodarki 'the condition of the Polish economy). Other words of the kind are: inspiracja 'inspiration' meaning a person who initiates an action or an event, horyzontalne plany 'horizontal plans' meaning extensive or longterm plans or certyfikat 'certificate' instead of the ordinary zaświadczenie or dyplom.

The widespread unification of languages suggests that the time language systems need to assimilate new units has become much shorter - natural languages often assimilate whole lexemes. The following words (and many more) have become part of everyday Polish: peeling, lifting, skype, spinning, jogging, rafting. ... These units are now treated on a par with words that are more established in natural languages. The causes of this process are multiple. Lexemes are borrowed, because people need words to denote new concepts and inventions. Moreover, some borrowings become popular as a result of trends, or people use them because it allows them to make their utterances shorter. (cf. Satoła-Staśkowiak, 2014, p. 187, also cf. Satoła-Staśkowiak, 2013b, pp. 21-30).

Discussion. Analytical tendencies are those that are leading to a decrease of morphemes in a language. It is in accordance with the long-term tradition of Indo- 
European language transformation in the direction of analitism. Having analysed the history of Slavic languages, it can be observed that the morphological level of Slavic languages is one of the most prevailing. In modern Slavic languages, nonliterary forms are spreading to literary language. Examples of analitism in our research also include the unconscious use of one case instead of another. Defining the concept of analitism, we have also made an assumption that the smaller the number of morphemes in a language, the larger the level of analitism. The concept of analitism which we have used is of traditional character, and stands in opposition to the concept of language synthetism.

Translations from analytic languages (e.g. English and French) amount to millions of pages. People also use foreign languages more and more often in interpersonal and international communication. These two processes render it impossible to stop profound systemic changes in European languages.

The modern EU language strategy is clearly aimed at the promotion of multilingualism. As members of this multilingual society we must be aware that languages tend to simplify and converge in terms of grammar and vocabulary. Thus, differences between language systems gradually smooth out and they attain greater unification. Despite the progressive development of a wide array of language policies, the EU does not have the necessary instruments to tackle these phenomena. Though the linguistic diversity has been raised to the status of a valuable heritage, the EU indeed remains unable to address the changes highlighted here. Subsequent steps in forging a more comprehensive multilingualism policy might therefore be required.

\section{References}

Cordell, K. (2013). The ideology of minority protection during the post-communist transition in Europe. In K. Cordell, T. Agarin, \& A. Osipov (Eds.), Institutional legacies of communism: Change and continuities in minority protection (pp. 77-89). Milton Park Abingdon Oxon: Routledge.

Coulmas, F. (1991). European integration and the idea of the national language: Ideological roots and economic consequences. In F. Coulmas (Ed.), A language policy for the European community (pp. 1-44). Berlin: De Gruyter. http://www.degruyter. com/view/books/9783110877137/9783110877137.1/9783110877137.1.xml

Council Regulation No 920/2005 of 13 June 2005 amending Regulation No 1 of 15 April 1958 determining the language to be used by the European Economic Community and Regulation No 1 of 15 April 1958 determining the language to be used by the European Atomic Energy Community and introducing temporary derogation measures from those Regulations. (2005, June 18). Official Journal, (L 156), pp. 3-4.

EEC Council 1958: Regulation No 1 determining the languages to be used by the European Economic Community. (1958, October 6). Official Journal, (017), pp. 385-386.

European Parliament decision on the adoption of a Statute for Members of the European Parliament. (2004, March 18). Official Journal, (E 068), p. 118.

Gramatyka konfrontatywna butgarsko-polska BPCG [GKBP]. (1988-2007). (Vols. 1-9). Sofia, Warszawa. [In Bulgar/Polish]

Häggman, J. (2014, July 7). Presentation of Johan Häggman, Policy Officer in the DG Translation of the European Commission, Brussels, 7 July 2014. 
Haselhuber, J. (2012). Mehrsprachigkeit in der Europäischen Union: Eine Analyse der EU-Sprachenpolitik, mit besonderem Fokus auf Deutschland; umfassende Dokumentation und Perspektiven für die Zukunft. Frankfurt, M.: Lang. (Duisburger Arbeiten zur Sprach- und Kulturwissenschaft, 92)

Kisiel, A., Satoła-Staśkowiak, J., \& Sosnowski, W. (2014). O rabote nad mnogoiazychnym slovarëm. In Prykladna linhvistyka ta linhvistychni tekhnolohï (MEGALING-2012) (pp. 111-121).

Korpus Języka Bułgarskiego IBE BAN. (n.d.). Retrieved 5 November 2014, from http: //search.dcl.bas.bg/

Korpus Języka Rosyjskiego. (n.d.). Retrieved 5 November 2014, from http://www . ruscorpora.ru/

Koseska-Toszewa, V. (2006). Gramatyka konfrontatywna bułgarsko-polska (Vol. 7: Semantyczna kategoria czasu). Warszawa: SOW.

Koseska-Toszewa, V., \& Gargov, G. (1990). Bŭlgarsko-polska sŭpostavitelna gramatika (Vol. 2: Semantichnata kategoriia opredelenost/neopredelenost). Sofiia: BAN.

Koseska-Toszewa, V., Korytkowska, M., \& Roszko, R. (2007). Polsko-bułgarska gramatyka konfrontatywna. Warszawa: Wydawnictwo Akademickie Dialog.

Koseska-Toszewa, V., Satoła-Staśkowiak, J., \& Sosnowski, W. (2013a). From the problems of dictionaries and multi-lingual corpora. Cognitive Studies / Études cognitives, 13, $113-122$.

Koseska-Toszewa, V., Satoła-Staśkowiak, J., \& Sosnowski, W. (2013b). O rabote nad knizhnymi i èlektronnymi slovariami s pol'skim, bolgarskim i russkim iazykami. In Prykladna linhvistyka ta linhvistychni tekhnolohï (MEGALING-2012) (pp. 124-135).

Kruse, J. (2012). Das Barcelona-Prinzip: Die Dreisprachigkeit aller Europäer als sprachenpolitisches Ziel der EU. Frankfurt, M.: Lang. (Duisburger Arbeiten zur Sprach- und Kulturwissenschaft)

Labrie, N. (1993). La construction linguistique de la Communauté Européenne. Paris: H. Champion.

Maćkiewicz, J. (2001). Wyrazy międzynarodowe (internacjonalizmy) we współczesnym języku polskim. In J. Bartmiński (Ed.), Wspótczesny język polski (pp. 555-562). Lublin: Wydawnictwo Uniwersytetu Marii Curie-Skłodowskiej.

Markowski, A. (2004). O pojęciu i typach internacjonalizmów semantycznych. Poradnik Językowy, 2, 39-50.

Milian i Massana, A. (2002). Le principe d'égalité des langues au sein des institutions de l'Union européenne et dans le droit communautaire, mythe ou réalité? Revista de Llengua $i$ Dret, Journal of Language and Law, 38, 48-91.

Miodek, J. et al. (2010). Jak pisać o Funduszach Europejskich? Warszawa: MRR.

Miodunka, W. (1999) Język polski poza Polską. In W. Pisarek (Ed.), Polszczyzna 2000: Orędzie o stanie języka na przełomie tysiacleci (pp. 306-325). Warszawa, Kraków: Rada Języka Polskiego przy Prezydium Polskiej Akademii Nauk, Ośrodek Badań Prasoznawczych Uniwersytetu Jagiellońskiego.

Nic Craith, M. (2006). Europe and the politics of language: Citizens, migrants and outsiders. Basingstoke, Hampshire: Palgrave Macmillan. (Palgrave studies in minority languages and communities)

Pozzo, B. \& Jacometti, V. (Eds.). (2006). Multilingualism and the harmonisation of European Law. Alphen aan den Rijn: Kluwer Law International.

Règlement $\mathrm{n}^{\circ} 1$, portant fixation du régime linguistique de la Communauté européenne de l'énergie atomique. (1958, October 6). Official Journal, (017), pp. 401-402.

Resolution on the multilingualism of the European Community. (1982, November 8). Official Journal, (C 292), pp. 96-97. 
Ricci, G. (2006). Controlled Multilingualism in Parliamentary Practice. In B. Pozzo \& V. Jacometti (Eds.), Multilingualism and the harmonisation of European Law (pp. 131-146). Alphen aan den Rijn: Kluwer Law International.

Rindler Schjerve, R. (2011). Aktuelle Tendenwen in der europäischen Sprachenpolitik. In P. Cichon \& M. Mitterauer (Eds.), Europasprachen, Studien Zu Politik und Verwaltung (pp. 145-156). Wien: Böhlau.

Rindler Schjerve, R. \& Vetter, E. (2012). European multilingualism: Current perspectives and challenges, Multilingual matters. Bristol: Multilingual Matters.

Rusek, J. (1964). Deklinacja i użycie przypadków w triodzie Chłudowa: Studium nad rozwojem analityzmu w języku bułgarskim. Wrocław, Warszawa, Kraków: Wydawnictwo PAN.

Satoła-Staśkowiak, J. (2013a). Contemporary contrastive studies of Polish, Bulgarian and Russian Neologisms versus language corpora. Cognitive Studies / Études cognitives, 13, 143-160.

Satoła-Staśkowiak, J. (2013b). Neologizmy bułgarskie, polskie i rosyjskie w ujęciu konfrontatywnym. In D. Blagoeva, S. Kolkovska, \& M. Lishkova (Eds.), Problemi na neologiiata $v$ slavianskite ezitsi (pp. 21-30). Sofiia: BAN.

Satoła-Staśkowiak, J. (2013c). Polskie i bułgarskie neologizmy znaczeniowe. In D. Blagoeva, S. Kolkovska, \& M. Lishkova (Eds.), Problemi na neologiiata v slavianskite ezitsi (pp. 218-230). Sofiia: BAN.

Satoła-Staśkowiak, J. (2014). Different aspects of neosemantization on the example of the Polish and Bulgarian language. Cognitive Studies / Études cognitives, 14, 183-191. http://dx.doi.org/10.11649/cs. 2014.015

Scheidhauer, C. (2001). Comment la défense des langues régionales est devenue une politique européenne. In L'opinion européenne 2001 (pp. 65-84). Paris: Presses de Sciences Po.

Stanisheva, D. (1968). K probleme ustanovleniia v iazyke sistem variantov (na materiale sintaksisa slavianskikh iazykov). Izvestiia na instituta za bŭlgarski ezik (Pt. 16).

Stanisheva, D. (1980). Iz istoriiata na bŭlgarskoto sklonenie. Godishnik na Sofǐskiia universitet "Kliment Orkhidski", fakultet po slavianski filologii, 74, (3) Ezikoznanie.

Stanisheva, D. (1982). Lokal'naia oppozitsiia padezhel VIN-LOK v istorii bolgarskogo, drevnerusskogo i belorusskogo iazykov. Godishnik na Sofǐskiia universitet "Kliment Orkhidski", fakultet po slavianski filologii, 76, (1) Ezikoznanie.

Stieber, Z. (1979). Zarys gramatyki porównawczej języków słowiańskich. Warszawa: PWN.

Uličný, O. (2013). Poznámky $k$ analytizaci v slovanských jazycích a ke struktuře jedné české NP s adnominálním genitivem. Olomouc.

Woehrling, J.-M. (1992). Institutions européennes et droits lingustiques des minorités. In H. Giordan (Ed.), Les Minorités En Europe - Droits Linguistiques et Droits de l'Homme (pp. 509-521). Paris: Kimé.

Zemskaia, E. A. (1983). Russkaia razgovornaia rech' (fonetika, morfologiia, leksika, zhest). Moskva.

Zemskaia, E. A. (2003). Russkiǔ iazyk kontsa XX veka: Norma ne zapret, a vybor. In Z. Rudnik-Karwatowa (Ed.), Procesy innowacyjne w językach słowiańskich. Warszawa: SOW. (Prace Slawistyczne, 114). 


\section{Acknowledgment}

This work was supported by a core funding for statutory activities form the Polish Ministry of Science and Higher Education.

The authors declare that they have no competing interests.

The authors' contribution was as follows: concept of the study: first author; data analyses: second author; wrote the manuscript: first and second author.

This is an Open Access article distributed under the terms of the Creative Commons Attribution 3.0 PL License (http://creativecommons.org/licenses/by/3.0/pl/), which permits redistribution, commercial and non-commercial, provided that the article is properly cited.

\section{(C) The Authors 2015}

Publisher: Institute of Slavic Studies, PAS, University of Silesia \& The Slavic Foundation 